\title{
Eisenmenger syndrome
}

INSERM

\section{Source}

INSERM. (1999). Orphanet: an online rare disease and orphan drug data base.

Eisenmenger syndrome. ORPHA:97214

Eisenmenger syndrome (ES) is a form of pulmonary arterial hypertension (PAH) associated with unoperated congenital heart disease and is characterized by congenital heart malformations with reversed or bi-directional shunting through an intra-cardiac or intervascular (usually aorto-pulmonary) communication with the development of PAH. 